\title{
THE POTENTIAL ROLE OF THE INTERNAL AUDIT ACTIVITY IN THE INTEGRATED REPORTING PROCESS
}

\begin{abstract}
Purpose - Integrated reporting has been identified as the future of corporate reporting. As it is a relatively new principal, the role of the internal audit activity in respect of integrated reporting has not yet been investigated. The purpose of this paper is to investigate and discuss the role that the internal audit activity can play in respect of integrated reporting.
\end{abstract}

Design/methodology/approach - The conceptual discussion of this paper is based on an objective review of relevant literature, both practitioner and academic.

Findings - The internal audit activity through risk based assurance and consulting services and its knowledge of the business is uniquely positioned to contribute towards integrated reporting.

Originality/value - This paper identifies the value the internal audit activity can contribute towards integrated reporting.

Keywords - Integrated reporting, Internal audit, Risk management, Governance, Stakeholders

\section{INTRODUCTION}

The financial scandals, financial recession, globalisation, the growth in information technology and the rise of social media have resulted in stakeholders being more vocal and insistent with regard to their needs in relation to corporate reporting. Stakeholders not only have a need for information that: supports company decision making; displays an understanding of the social, environmental and commercial environment; and considers the needs of all stakeholders (Dumitru, Glăvan, Gorgan, \& Dumitru, 2013) but also a company's ability to create and sustain value in an ever changing economic environment (Marx \& Mohammadali-Haji, 2014). Even though all stakeholders believe they should be treated equally, most often it is only the corporate reporting needs of the capital contributing stakeholders that are considered by management of organisations.

To this end, the principle of integrated reporting aims to "provide stakeholders with a report on the strategy, performance and activities of the organisation in a manner that would allow stakeholders to assess the ability of the organisation to create and sustain value in the short-, medium-, and long term." (IIRC, 2011). Integrated reporting attempts to make management and the board of directors aware of the significance of integrated thinking in harvesting value creation and the importance of stakeholder centeredness in decision making and disclosure (Roberts, 2013). Integrated thinking is defined as "the active consideration by an organisation of the relationships between its various operating and functional units and the capitals that the organization uses or affects" (IIRC, 2011). The principle of integrated reporting allows management to focus on the interdependent ability of various functions and the impact thereof on the future of the organisation. The introduction of integrated reporting is yet another development in the progression of corporate reporting striving to improve reporting by addressing the demands of various stakeholders (de Villiers, Rinaldi, \& Unerman, 2014).

In responding to the business environmental stimuli, internal audit has adapted its methods and practices to continue to add value to organisations in compliance with its mandate as encapsulated in the definition of internal auditing (IIA, 2011). For the internal audit activity to continually add value to its stakeholders, it must focus on the risks that impact the ability of the organisation to archive its objectives, the resources deployed by the organisation and the relationships between the organisation and its stakeholders (PWC, 2014).

The focus of the internal audit activity to provide both assurance and advisory services to organisations speaks to the wide ambit of internal auditing services provided (Reding, et al., 2011). The internal audit activity, through adopting a riskbased approach, displaying professional scepticism, and its actual and perceived independence, provides assurance to the board of directors (through the audit committee) and management that 
Proc. of the Third Intl. Conf. on Advances in Management, Economics and Social Science - MES 2015.

Copyright (C) Institute of Research Engineers and Doctors, USA .All rights reserved.

ISBN: 978-1-63248-081-1 doi: 10.15224/ 978-1-63248-081-1-106

all significant risks impacting the organisation's going concern status have been identified and that adequate controls have been implemented to effectively mitigate these risks within its approved risk-appetite (IIA, 2011). To achieve this, the objectives and risk environment of the organisation are evaluated and, based upon the results, the focus areas of the internal audit activity are determined (IIA, 2011). The assurance provided by the internal audit activity is focused on those functions that are best placed to ensure that the organisation meets its objectives. Activities and functions performed within an organisation all work together in an integrated manner to achieve its organisational objectives. As such, the internal audit activity, through adopting a risk-based approach, is not driven by silo, departmental thinking, but rather by value adding, risk-based, objectives driven thinking. The reports provided by the internal audit activity should be used by management and the board of directors to compile the integrated report.

Management and the board of directors can derive much needed information regarding the interrelationship of various units within the organisation by reviewing the information provided by the internal audit activity. In addition, the internal audit activity should have the added benefit of organisational strategic involvement allowing management to receive independent and objective assurance about the veracity of the information disclosed in the integrated report.

The article explains how management can use the work performed by the internal audit activity to assist with their integrated reporting process.

\section{THEORETICAL FRAMEWORK}

\subsection{Financial reporting}

The devastation of the global financial crises in 2008, the horror of the Enron scandal in 2001, and the outrage following the WorldCom scandal in 2002, have left company stakeholders, all over the world, sceptical and disillusioned with the state of corporate reporting (Eccles, Krzus, \& Watson, 2010). Stakeholders are left questioning how it is possible for organisations that produce annually audited financial statements in accordance with international financial reporting standards (IFRS) and in the United States the general accepted accounting principles (US GAAP) to fail (Deloitte, 2012). This is especially so when one considers that, in relation to the Conceptual Framework of Financial Reporting (SAICA, 2014), financial statements must be compiled on the going concern basis, and in accordance with the International Standards on Auditing (ISA) 570 (SAICA, 2014), external auditors must provide an opinion on whether the financial statements fairly represent the organisation as a going concern.

The objective of financial reporting is embedded in the needs of the users (Zeff, 2012). Skinner and Milburn (2001) proclaimed that the objective of financial reporting throughout accounting history was to portray the stewardship of management (Zeff, 2012).

The emergence of decision-usefulness of financial statements in the early 1950s underpinned the objective of financial reporting in modern accounting literature (Zeff, 2012). Zeff argues that the objective of financial reporting before the emergence of decision-usefulness was stewardship accountability. Historical information provides an indication of stewardship accountability, and is focused on company shareholders. The current demand for decision-usefulness of financial reporting broadens the target group of corporate reporting to stakeholders rather than only shareholders. The demand for decision-usefulness places the emphasis on future-orientated thinking and corporate reporting. It is important to note that financial statements serve as a monitoring and performance indicator between shareholders of the organisation and management; management and employees and the organisation and creditors (Zeff, 2012).

\subsection{Integrated reporting}

As a global practice, integrated reporting is still in its infancy (Hindley \& Buys, 2012). It can be agreed that integrated reporting is yet another step in the evolution of corporate reporting similar to previous innovations, including value-added statements, social accounting, environmental reporting, Triple Bottom Line reporting and sustainability reporting (Higgins, Stubbs, \& Love, 2014). It has been proven that financial reporting, i.e. the reporting of historical information and/or events, does not adequately address the long-term 
Proc. of the Third Intl. Conf. on Advances in Management, Economics and Social Science - MES 2015.

Copyright (C) Institute of Research Engineers and Doctors, USA .All rights reserved.

ISBN: 978-1-63248-081-1 doi: 10.15224/ 978-1-63248-081-1-106

profitability and sustainability of organisations (de Boer, 2013).

The IIRC Discussion Paper (IIRC, 2011) advocated the notion of streamlining company reporting into one integrated report (Deloitte, 2012). This contrasted with earlier social and environmental disclosures, where the social and environmental information was not integrated with the financial information (Dey \& Burns, 2010; Hopwood et al., 2010). The reason for this integration was to provide both financial and non-financial information in a single future-orientated document (Eccles, Krzus, \& Watson, 2010).

Integrated reporting based on "integrated thinking" would seem to be the answer to many of the demands made by stakeholders today. However, the success of integrated reporting depends not only on the execution thereof (Athma \& Rajyalaxmi, 2013), but also on the guidance provided by the IIRC to ensure that the integrated report is true to the fundamental nature of the principle of integrated reporting .

Although the biggest challenge faced by organisations that apply integrated reporting is how to implement the principle within organisations, it is believed that the concept will only reach its full potential upon the introduction of integrated assurance (Stubbs \& Higgins, 2014).

The conceptual groundwork of integrated reporting was undertaken by two separate bodies (Abeysekera, 2012). The most prominent was the International Integrated Reporting Council (IIRC) established in 2010 by the Prince of Wales' Accounting for Sustainability Project and the Global Reporting Initiative (GRI) (Eccles, Krzus, \& Watson, 2010). The IIRC is an international body of regulators, investors, businesses, accountancy firms and associations aimed at “creating a globally accepted reporting framework which brings together financial, environmental, social and governance information in a clear, concise, consistent and comparable format". The aim of the IIRC is to "help business to take more sustainable decisions and enable investors and other stakeholders to understand how an organisation is really performing". (Eccles, Krzus, \& Watson, 2010).
The King Report on Corporate Governance (King III) is the second of these two bodies and it laid the groundwork for integrated reporting in South Africa. It is important to note that Mervyn King is the chairperson of the IIRC and the King Committee, as well as being a former chairperson of the GRI. King III was introduced in 2009, and, despite being a voluntary code of governance, with effect from 2011 compliance with the King III principles became a mandatory requirement for all companies listed on an apply or explain basis.

The IIRC published its first Discussion Paper in 2011 to inform the public of the purpose of the $<\mathrm{IR}>$ and to lay the ground work for a general understanding of integrated reporting (Flower, 2015). The International Integrated Reporting Framework ( $\langle\mathrm{IR}\rangle$ framework) was published in 2013 by the IIRC in order "to establish Guiding Principles and Content Elements of an integrated report..." (IIRC, 2013). The final <IR> Framework was compiled after consideration of submissions to a Consultation Draft on the proposed <IR> Framework.

\subsection{Internal auditing}

Although the origins of internal auditing date back to ancient times, it only started to play an important role in organisational strategy and management in the 1940s when shareholders required more assurance when dealing with the agency problem (Castanheira, Rodrigues, \& Craig, 2010). The field of internal auditing has experienced various changes over the last decade, ranging from riskbased auditing to strategic representation within organisations. However, Lenz \& Sarens (2012) suggest that internal auditing is still searching for a unique selling proposition, a niche market relevant only to its existence.

The International Professional Practices Framework (IPPF) provides mandatory actions and voluntary guidance as to the responsibilities and objectives of the internal auditing activity (IIA, 2011). The definition of internal auditing defines it as being "an independent, objective assurance and consulting activity designed to add value and improve an organization's operations. It helps an organization accomplish its objectives by bringing a systematic, disciplined approach to evaluate and improve the effectiveness of risk management, control and governance processes" (IIA, 2011). 
Proc. of the Third Intl. Conf. on Advances in Management, Economics and Social Science - MES 2015.

Copyright (c) Institute of Research Engineers and Doctors, USA .All rights reserved.

ISBN: 978-1-63248-081-1 doi: 10.15224/ 978-1-63248-081-1-106

From the definition it can be determined that the internal audit activity should provide two very distinctive services. The first, assurance services, as defined by the IIA Standards, refers to "an objective examination of evidence for the purpose of providing an independent assessment on governance, risk management and control processes for the organisation" (IIA, 2011). For assurance services to be of value, an internal audit activity relies heavily on the notion of independence, both of mind and appearance (Stewart \& Subramaniam, 2010).

By contrast, the second, consulting services, relates to "advisory and related client service activities, the nature and scope of which are agreed with the client, are intended to add value and improve an organization's governance, risk management, and control processes without the internal auditor assuming management responsibility" (IIA, 2011). One of the material differences between assurance and consulting services is the independence of procedures being performed. For assurance services, the internal audit activity is required to provide "independent assurance" (IIA, 2011), through procedures compiled based upon a risk assessment of the auditable units. By comparison, consulting services relates to advisory and related client service activities aimed at improving an organisation's governance, risk management, and control processes, but without the internal auditor assuming management responsibility.

It is very important to realise that in terms of the IPPF, the internal audit activity must validate its existence by "adding value" (IIA, 2011) to the organisation. The concept of adding value has been defined by the IIA as, "The internal audit activity adds value to the organisation (and its stakeholders) when it provides objective and relevant assurance, and contributes to the effectiveness and efficiency of governance, risk management and control processes" (IIA, 2011).

While performing assurance services, IIA Standard 2010 - Planning requires the chief audit executive to be responsible for establishing risk-based plans to determine the priorities of the internal audit activity. The risk must be based on the objectives of the organisation (IIA, 2011), which should correlate with the manner in which it creates value as encapsulated in the integrated report. The internal audit plan must be reviewed regularly to ensure its ongoing relevance in addressing the risks identified and to monitor the performance of the internal audit activity (Reding, et al., 2011).

In compiling the annual internal audit plan the chief audit executive must review the annual risk assessment, the organisation's risk management framework and the risk appetite as agreed upon by the board of directors (IIA, 2011). In addition to these documents, the chief audit executive should also take into consideration the expectations of senior management, the board of directors and other stakeholders (IIA, 2011).

In relation to IIA Standard 2120 - Risk Management, the internal audit activity is also responsible for evaluating the organisation's risk management process. When performing this activity, an internal audit should ensure that the organisation's objectives are aligned with the mission; that material risks are identified and assessed; that appropriate mitigating actions have been taken in line with the organisation's risk appetite; that risk management processes are continuously monitored by management; and that risk communication is adequate (IIA, 2011).

\section{CONCEPTUAL FRAMEWORK}

Financial scandals the world over have left stakeholders questioning the reliability of financial reporting, particularly as an indicator of the longterm profitability and economic sustainability of organisations. This disillusionment included scepticism in respect of the reliability of both external and internal assurance services. The origin of the discord between shareholders and management can be traced back to the separation between ownership and management control and the resultant information asymmetry, skewed in favour of management. Despite various interventions, such as the appointment of a board of directors, existing financial reporting and assurance practices do not adequately provide stakeholders with the necessary levels of confidence that the inadequacies arising from the agency problem have been addressed. Recent history has shown that neither corporate reporting, nor external or internal assurance services, currently provide stakeholders with the required assurance about the integrity and 
Proc. of the Third Intl. Conf. on Advances in Management, Economics and Social Science - MES 2015.

Copyright $(\subseteq$ Institute of Research Engineers and Doctors, USA .All rights reserved.

ISBN: 978-1-63248-081-1 doi: 10.15224/ 978-1-63248-081-1-106

adequacy of the information provided to ensure long-term organisational profitability and economic sustainability. It is suggested that integrated reporting is the natural evolution of corporate reporting, in response to the demands of stakeholders the world over.

The advent of integrated reporting is introducing a new era in corporate reporting (Adams, 2015). Integrated reporting represents the evolution of corporate reporting from being focussed on the past and what has occurred to focusing, through integrated thinking, on the future, the opportunities available and the resources required to achieve them (de Boer, 2013). Owing to a risk immersed economic environment, management is required to adapt systems and processes to mitigate against avoidable material risks. As risks do not exist in isolation but rather in relation to the actions taken and processes performed, the principle of integrated thinking would serve management well. The principles embedded in risk management align in many instances with that of integrated reporting. It is also clear that stakeholders, through social media and globalisation, are more involved in and knowledgeable about organisational operations as well human and societal rights. It would therefore appear that, based on the definition and goal of integrated reporting and the current economic climate, that, despite being a voluntary intervention, management is obliged to implement the integrated reporting principles which would assist the organisation not only to achieve its objectives, but also to demonstrate a commitment to its longer term sustainability, while comprehensively accounting to its stakeholders.

To this end, it is posited that the internal audit activity can assist management and the board of directors in the implementation of integrated reporting within an organisation through the provision of both assurance and consulting services. The internal audit activity's independent risk-based, value adding approach, together with its intimate knowledge of the organisation, uniquely positions it to assist management to identify the relevant capitals for the organisation; provide independent assurance about the reliability of the systems producing the reported information as well as the veracity of the disclosures; to coordinate the inter-relationship between the various units; and to ensure that the future risks likely to impact business operations have been identified and are being effectively mitigated within the organisation's risk appetite.

Through the adoption of a risk-based internal auditing approach, the assurance services of the internal audit activity are focused on those activities that are most likely to materially impact business operations. The process of reporting on audit findings and the making of recommendations provide management and the audit committee with information which can be used to improve their integrated reporting practices while also providing assurance as to the veracity of the disclosures that will be included in the integrated report. This does not, however, suggest that the internal audit activity should provide assurance to external stakeholders about the veracity of the published integrated report.

As indicated before, the implementation of integrated reporting by the management of an organisation would be raised by an internal audit activity as a risk. As such the internal audit activity should address the implementation of integrated reporting in its annual internal audit plan. It is, therefore, likely that what is highlighted in relation to the annual internal audit plan will likewise contribute to the organisation's integrated report and provide the board of directors, through the audit committee, with assurance as to the reliability of processes used to gather the information contained in the integrated report.

\section{CONCLUSION}

The internal audit activity focuses its assurance resources on the processes and procedures within the organisation with the highest risk and the greatest likelihood of affecting the organisation's ability to reach its objectives. For the purposes of integrated reporting, an organisation must identify the resources and relationships that are responsible for value creation. It can be submitted that, in most instances, the high risk processes and procedures identified in the internal audit plan will inevitably correlate with the resources and relationships identified for the purposes of producing the integrated report.

An efficient and effective internal audit activity would therefore be in a position to provide 
Proc. of the Third Intl. Conf. on Advances in Management, Economics and Social Science - MES 2015.

Copyright (c) Institute of Research Engineers and Doctors, USA .All rights reserved.

ISBN: 978-1-63248-081-1 doi: 10.15224/ 978-1-63248-081-1-106

assurance to management, the audit committee and the board of directors on most of the dimensions included in the integrated report.

Through strategic coordination, the internal audit activity can provide assurance to management, the audit committee and the board of directors on the veracity of most of the capitals disclosed in the integrated report. In addition, through the provision of consulting services the internal audit could advise management on the resources and relationships that are important in respect of integrated reporting, while providing recommendations for improvement. Even though the objective of the internal audit is usually to provide assurance only to internal stakeholders, shareholders could benefit greatly through a coordination of the various functions. In addition, by disclosing that the internal audit has reviewed the underlying systems and/or even the published integrated report, organisations can provide stakeholders with confidence that the disclosures have been reviewed by a party independent of management, despite it not the objective of internal auditing. 
Proc. of the Third Intl. Conf. on Advances in Management, Economics and Social Science - MES 2015.

Copyright (C) Institute of Research Engineers and Doctors, USA .All rights reserved.

ISBN: 978-1-63248-081-1 doi: 10.15224/ 978-1-63248-081-1-106

\section{REFERENCES}

Abeysekera, I. (2012). A template for integrated reporting. Journal of Intellectual Capital, 14(2), 227245.

Athma, P., \& Rajyalaxmi, N. (2013). Integrated reporting: The global scenario. The IUP Journal of Accounting Research \& Audit Practices, 12(3), 7-18.

Castanheira, N., Rodrigues, L. L., \& Craig, R. (2010). Factors associated with the adoption of riskbased internal auditing. Managerial Auditing Journal, 25(1), 79-98.

Dey, C., \& Burns, J. (2010). Integrated reporting at Novo Nordisk. In A. Hopwood, J. Unerman \& J. Fries (Eds), Accounting for sustainability: Practical insights, 215-232. London: Earthscan.

de Boer, Y. (2013). Integrated reporting will only become meaningful when companies begin strategising for future value. Accountancy SA, 12/2012, 34.

de Villiers, C., Rinaldi, L., \& Unerman, J. (2014). Integrated reporting: Insights, gaps and an agenda for future research. Accounting, Auditing \& Accountibity Journal, 27(7), 1042-1067.

Deloitte. (2012). Integrated Reporting: Navigating your way to a truly Integrated Report. Johannesburg: Deloitte.

Dumitru, M., Glăvan, M. E., Gorgan, C., \& Dumitru, V. F. (2013). International Integrated Reporting Framework: A Case Study In The Software Industry. Annales Universitatis Apulensis Series Oeconomica, 15(1), 24-39.

R. G. Eccles, M. P. Krzus, \& L. A. Watson, One Report: Integrated Reporting for a Sustainable Stategy (pp. 1-17). Hoboken, New York: Wiley.

Flower, J. (2015). The International Integrated Reporting Council: A story of failure. Critical Perspectives on Accounting, 27, 1-17.

Higgins, C., Stubbs, W., \& Love, T. (2014). Walking the talk(s): Organisational narratives of integrated reporting. Accounting, Auditing \& Accountability Journal, 27(7), 1090-1119.

Hindley, T., \& Buys, P. W. (2012). Integrated reporting compliance with the global reporting initiative framework: An analysis of the South African mining industry. International Business \& Economics Research Journal, 1249-1260.

Lenz, R., \& Sarens, G. (2012). Reflections on the internal auditing profession: What might have gone wrong? Managerial Auditing Journal, 27(6), 532-549.

Marx, Ben, \& Mohammadali-Haji, Ahmed (2014). Emerging trends in reporting: An analysis of integrated reporting practices by South African top 40 listed companies. Journal of Economic and Financial Sciences, 7(1), 231-250. 
Proc. of the Third Intl. Conf. on Advances in Management, Economics and Social Science - MES 2015.

Copyright (C) Institute of Research Engineers and Doctors, USA .All rights reserved.

ISBN: 978-1-63248-081-1 doi: 10.15224/ 978-1-63248-081-1-106

PricewaterhouseCoopers Limited, (PWC). (2014). 2014 state of the internal audit profession study. Available at: www.pwc.com/en.../pwc-state-of-the-internal-audit-profession-2014.pdf. [Accessed on 2015-05-03]

Reding, K. F., Sobel, P. J., Anderson, U. L., Head, M. J., Ramamoorti, S., Salamasick, M., et al. (2011). Internal Auditing: Assurance \& Consulting Services. Florida: The Institute of Internal Auditors Research Foundation.

Roberts, L. (2013). Integrated reporting is changing how companies communicate with their stakeholders. But this process has just begun, with new benchmarks planned for release in 2013. Accountancy SA, 32-33.

Stewart, J., \& Subramaniam, N. (2010). Internal audit independence and objectivity: Emerging reserach opportunities. Managerial Auditing Journal, 25(4), 328 - 360.

The Institute of Directors (IOD). (2009). King Report on Governance For South Africa 2009. Johannesburg: Institute of Directors South Africa.

The International Accounting Standards Board (IASB). (2014). Conceptual Framework for Financial Reporting. Available at: http://integratedreporting.org/resources/ [Accessed on 2015-05-26].

The International Integrated Reporting Council (IIRC). (2013). Capitals Background Paper For <IR>. Available at: http://integratedreporting.org/resources/ [Accessed on 2015-05-20]

The International Integrated Reporting Council (IIRC). (2013). The Consultation Draft of the International <IR> Framework. Available at: http://integratedreporting.org/resources/ [Accessed on 2015-05-14]

The International Integrated Reporting Council (IIRC). (2013). The <IR> Framework.. Available at: http://integratedreporting.org/resources/ [Accessed on 2015-05-14]

The International Integrated Reporting Council (IIRC). (2011). The International Integrated Reporting Discussion Paper. Available at: http://integratedreporting.org/resources/ [Accessed on 2015-05-14]

The Institute of Internal Auditors (IIA). (2011). International Profesional Practice Framework (IIA Standards). Florida: Institute of Internal Auditors.

The Southern African Institute of Chartered Accountants. (SAICA). 2012. A Guide through International Financial Reporting Standards - Part A: The Conceptual Framework and requirements. London: IFRS foundation.

Zeff, S. A. (2013). The Objectives of Financial Reporting: A Historical Analysis. The Accounting and Business Research Journal, 43(4), 262-327. 